\section{ON THE DISTRIBUTION OF CALCULOUS DISEASE} IN NORFOLK.

Br CHARLES B. PLOWRIGHT, M.R.C.S., F.L.S., Surgeon to the West Norfolk and Lynn Hospital.

THE data from which the following paper has been compiled, consist of 1,936 cases of stone, which have either been the subject of operation, or of post mortem examination, and of which the localities have been recorded. These have been derived from the following sources. Public Practice.

Norfolk and Norwich Hospital, 1772 to $1885 \ldots$ 1,503 cases.

West Norfolk and Lynn Hospital, 1835 to 1885124 ,

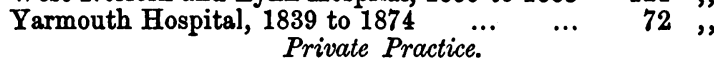

Dr. Lubbock, Mr. C. M. Gibson, Mr. R. E. Gibson, and Mr. Cadge, Norwich ; Dr. John Lowe, Mr. G. B. Sweeting, and Mr. W. G. Walford, King's Lynn ; and Mr. R. Marriott, Swaffham

$$
\begin{array}{ccccc}
\cdots & \ldots & \ldots & \ldots & \frac{237}{1,936}
\end{array}
$$

Of these, the localities of 1,760 Norfolk cases were placed on a map of the county; they were then transferred to an ordnance-map (one inch to the mile); the geological map, as far as this has, up to the present, been published, being employed. The distribution of the cases was finally again checked from the original list. ${ }^{1}$

It happens that the ordnance-map of the county is divided from west to east, by the sheets in which it is published, into three nearly equal sections, of which the western section contains 677 square miles; the central, 705 square miles; and the eastern, 640 square miles. From the above materials we find that, taking the entire county, one case of stone occurs in every 1.1 square mile. The proportion, however, differs in each of the sections, the disease increasing in frequency from west to east. Thus

$\begin{array}{llcl} & \begin{array}{c}\text { Western } \\ \text { Section. }\end{array} & \begin{array}{c}\text { Central } \\ \text { Section. }\end{array} & \begin{array}{l}\text { Eastern } \\ \text { Section. }\end{array} \\ \text { One case in every ... } \ldots & \ldots .0 & 1.5 & .6 \text { square miles } \\ \text { Excluding towns of more } & & & \end{array}$

xcluding

$\begin{array}{lllll}\text { than } 10,000 \text { inhabitants } & 3.7 & \ldots & 1.5 & 1.09\end{array}$

In the towns of more than 10,000 population, 1 case occurs: in King's Lynn, .11; in Great Yarmouth, .04; in Norwich, 0.3 ; to each square mile.

Parallel to these arbitrary divisions, the Great Ouse runs northwards through nearly the eentre of West Norfolk, emptying itself into the Wash on the west side of the town of King's Lynn. It has long been a matter of observation on the part of the surgeons of the Lynn Hospital that they seldom, if ever, have a stone case from Marshland, that is, west of the Ouse. Since 1865 (twenty years), 53 calculi have been added to the collection at this hospital; 50 of these came from the east side of the river, 3 only from the west. Of these 3,1 was from Long Sutton, in Lincolnshire ; 1 from Friday Bridge in Cambridgeshire; and 1 from Marshland, Terrington St. Clement's ; this last was removed by myself, from a young child, whose parents had immigated into Marshland, from High Norfolk, about a year before its birth. By taking the more extended data on the map, which include cases cut in Norwich in 1786, 1799 (probably two brothers), 1811,1824, and 1825, and one which was crushed in Lynn Hospital in 1846, and cut in 1852, thus counting as two cases, we find that in High Norfolk, that is east of the Ouse, one case occurs in every 2.5 square miles ; while in Marshland, that is west of the river, one case occurs in every 8.2 square miles. It must further be remembered that some years ago labour was much better paid in Marshland than in High Norfolk, so that immigrations into Marshland were constantly taking place from the last named district; and, moreover, prior to 1820 , the Great Ouse, in the lower part of its course, ran considerably more to the westward than it does now. The limitation of the disease by the river in question, is a matter of great interest from an etiological point of view. Not only do the cases come quite up to the east bank of the river from Southery to Lynn, but they also come quite up to the coast from Lynn to Yarmouth. So much is this the case, that there is scarcely a village on the seaboard of the county in which one or more cases have not occurred; the comparatirely important town of Hunstanton being one of the very few exceptions. On the southern boundary of the county the cases extend, with little if any diminution in frequency, into the adjoining one of Suffolk.

3 At the meeting of the East Anglian Branch, held at Cambridge, in June last, this map was exhibited, for which occasion the present communication was prethis map was exhibited, for which occasion the present communication was prepared. It is obvious that the data given above do not show the actual number of as far as I have been able to arrive at it.
In East Norfolk, the cases tend to follow the course of certain of the rivers, namely, the Bure, the Waveney, the Tese, and the Ket. This is not observable with the rivers in other parts of the county.

The geological survey-maps for West Norfolk and for the district round East Dereham have not yet been published. The subjoined remarks, therefore, apply only to East Norfolk and Mid Norfolk, excepting the district round Dereham. Excluding the large towns, Norwich and Great Yarmouth; 801 cases occur upon the following formations as nearly as can be ascertained.

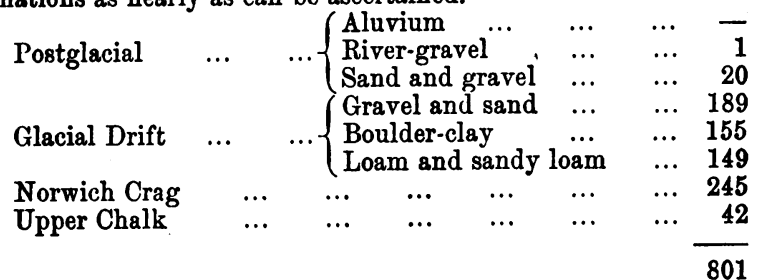

The extensive tract of chalk which occupies West Norfolk does not appear in the above summary, but it will be remembered that this division of Norfolk produces only one stone-case in every three square miles, against one to every three-fifths of a square mile of East Norfolk. The rivers which the cases follow are those whose course is outlined by the Norwich Crag. Certain towns and villages are specially subject to the disease ; for example-

\begin{tabular}{|c|c|c|c|c|c|c|c|c|}
\hline & & & & & & & ber 0 & Caser \\
\hline 2,647 & $\ldots$ & $\ldots$ & Aylsham & $\ldots$ & $\cdots$ & .. & $\cdots$ & 23 \\
\hline 1,090 & $\ldots$ & $\ldots$ & North Elmh8 & & $\ldots$ & $\ldots$ & $\ldots$ & 14 \\
\hline 4,566 & $\ldots$ & $\ldots$ & Wymondham & $\ldots$ & $\cdots$ & $\ldots$ & $\ldots$ & 21 \\
\hline 470 & & $\ldots$ & Binham & $\ldots$ & $\ldots$ & $\ldots$ & $\ldots$ & 8. \\
\hline Others are & semp & or $n$ & dearly so. & & & & & \\
\hline 1,500 & $\ldots$ & $\ldots$ & Hunstanton & ... & $\cdots$ & $\cdots$ & $\cdots$ & 0 \\
\hline 1,407 & $\ldots$ & $\ldots$ & Watton & $\ldots$ & $\ldots$ & $\ldots$ & $\ldots$ & 0 \\
\hline 3,264 & $\ldots$ & $\ldots$ & Downham & $\because$ & $\ldots$ & $\cdots$ & $\cdots$ & 1 \\
\hline ljoining & llag & & times vary co & sid & bly. & & & \\
\hline $\begin{array}{r}1,127 \\
822\end{array}$ & $\cdots$ & $\cdots$ & Pulhan, St. & Mar & Mag & $\begin{array}{l}n \\
\text { in }\end{array}$ & $\cdots$ & $\begin{array}{l}2 \\
8\end{array}$ \\
\hline
\end{tabular}

The village of North Wootton, since 1865 , has had 1 case of lithotrity, 2 of lithotomy, 1 of urethral extraction, 1 of renal (uric acid), 3 of uric acid gravel $=8$ cases.

$\begin{array}{ccclcccc}324 & \ldots & \ldots & \text { North Wootton } & \ldots & \ldots & \ldots & 8 \\ 197 & \ldots & \ldots & \text { South Wootton } & \ldots & \ldots & \ldots & 0 \\ 345 & \ldots & \ldots & \text { Castle Rising } \ldots & \ldots & \ldots & \ldots & 0 \\ 195 & \ldots & \ldots & \text { Wolferton } \ldots & \ldots & \ldots & \ldots & 1\end{array}$

The three last named parishes surround $\dddot{N}^{\circ}$ orth Wootton on three sides, the sea bounding it on the fourth. Moreover, of the eight cases above named, seven occurred in one group of houses using the same water-supply.

Taking into consideration such facts as the above, together with the limitation of the disease by the Great Ouse and the riparian aggregation of the cases along the Bure, the Waveney, etc., and its absence from the other rivers, one cannot avoid the conclusion that continued observations on the distribution will eventually lead to some definite conclusions as to the cause of the frequency of the disease in Norfolk. In the present communication, however, this aspect of the subject is purposely avoided.

My best thanks are due to those gentlemen who have freely replied to my queries, and afforded me information, especially to $\mathrm{Mr}$. Cadge. For the calculations respecting the distribution of the disease in the various areas, my thanks are due to Mr. E. G. Mawbey, the borough surveyor of King's Lynn.

\section{SUGGESTED IMPROVEMENTS IN EXCISION OF THE KNEE-JOINT, AND IN THE LIGATURE OF LARGE ARTERIES. \\ By EDWARD THOMPSON, M.B., F.R.C.S.I., Surgeon to the Tyrone County Infirmary.}

THERe are some points in the treatment of excision of the knee-joint, both at the time of operation and subsequently, which seem to me to deserve particular attention. I have had a good many of these cases under treatment from time to time in the Tyrone Infirmary; and the suggestions I have now to make, and which I desire shortly to detail, are the outcome of my experience.

In the first place, I always make the first incision nearly straight across the limb, and as small in extent as possible; with one swoop of the knife the ligamentum patellæ is cut through, and the joint opened. 